\title{
p38 kinase mediates nitric oxide-induced apoptosis of chondrocytes through the inhibition of protein kinase C $\zeta$ by blocking autophosphorylation
}

\author{
J-S Kim ${ }^{1}$, Z-Y Park ${ }^{1}$, Y-J Yoo ${ }^{1}$, S-S Yu ${ }^{1}$ and J-S Chun ${ }^{\star 1}$ \\ ${ }^{1}$ Department of Life Science, Gwangju Institute of Science and Technology, \\ Gwangju, Korea \\ * Corresponding author: J-S Chun, Department of Life Science, Gwangju \\ Institute of Science and Technology, Pook-Gu, Gwangju 500-712, Korea. \\ Tel: + 82-62-970-2497; Fax: + 82-62-970-2484; \\ E-mail: jschun@kjist.ac.kr
}

Received 19.7.04; accepted 16.8.04; published online 21.1.05 Edited by $\mathrm{H}$ Ichijo

\begin{abstract}
This study investigated the molecular mechanisms underlying inhibition of protein kinase $\mathrm{C}$ (PKC) $\zeta$ by p38 kinase during nitric oxide (NO)-induced apoptosis of chondrocytes. Coimmunoprecipitation experiments showed that activation of p38 kinase following addition of an NO donor resulted in a physical association between $\mathrm{PKC} \zeta$ and $\mathrm{p} 38$ kinase. Direct interaction of p38 kinase with PKC $\zeta$ was confirmed in vitro using p38 kinase and $\mathrm{PKC} \zeta$ recombinant proteins. p38 kinase interacts with the regulatory domain of PKC $\zeta$ and its association blocked PKC $\zeta$ autophosphorylation. Micro LC-MS/MS analysis using recombinant proteins indicated that the interaction of p38 kinase with PKC $\zeta$ blocked autophosphorylation of PKC $\zeta$ on Thr-560, which is required for $\mathrm{PKC} \zeta$ activation. Collectively, our results demonstrate a novel mechanism of $\mathrm{PKC} \zeta$ regulation: following activation by the production of NO, p38 kinase binds directly to the $\mathrm{PKC} \zeta$ regulatory domain, preventing PKC $\zeta$ autophosphorylation on Thr-560, thereby inhibiting $\mathrm{PKC} \zeta$ activation.

Cell Death and Differentiation (2005) 12, 201-212.

doi:10.1038/sj.cdd.4401511

Published online 21 January 2005
\end{abstract}

Keywords: chondrocytes; nitric oxide; apoptosis; p38 kinase; PKC $\zeta$; autophosphorylation

\footnotetext{
Abbreviations: aPKC, atypical PKC; ATF, activating transcription factor; DMEM, Dulbecco's modified Eagle's medium; GST, glutathione $S$ transferase; MAP kinase, mitogen-activated protein kinase; NO, nitric oxide; Par-4, prostate androgen response-4; PDK-1, 3-Phosphoinositide-dependent protein kinase-1; PI3-K, phosphoinositide 3-OH kinase; PKC, protein kinase C; PS-PKC, pseudosubstrate region of human $\mathrm{PKC} \zeta$ 113-125; RT-PCR, reverse transcription-polymerase chain reaction; SNP, sodium nitroprusside; TUNEL, terminal deoxynucleotidyl transfermediated nick end labeling
}

\section{Introduction}

Protein kinase $C$ (PKC) comprises at least 10 structurally related phospholipid-dependent protein kinases. Each PKC isoform is a single polypeptide with an amino-terminal regulatory domain and a carboxyl-terminal catalytic domain. PKC isoforms can be grouped into three subclasses on the basis of their regulatory properties. The 'conventional' PKCs $(\alpha, \beta I, \beta I \mathrm{I}$ and $\gamma)$ require $\mathrm{Ca}^{2+}$ and diacylglycerol for activation, whereas 'novel' PKCs $(\delta, \varepsilon, \theta$ and $\eta)$ are activated by diacylglycerol but are $\mathrm{Ca}^{2+}$ independent. Unlike conventional and novel PKC isoforms, 'atypical' PKCs (aPKC) $\zeta$ and $\lambda / l$ are activated independent of either $\mathrm{Ca}^{2+}$ or diacylglycerol.

Although the regulatory mechanisms for atypical PKC activation remain largely unknown, it has been shown that phosphorylation of PKC and its interaction with other regulatory proteins plays an important role. ${ }^{1-3}$ The interaction of PKC isoforms with regulatory proteins determines subcellular localization as well as function. A variety of PKC binding proteins have been identified, including proteins that interact with active $\mathrm{PKC}$, anchoring proteins and substrates. ${ }^{2-4}$ In the case of $\mathrm{PKC} \zeta$, binding of Par- 4 to the regulatory domain inhibits $\mathrm{PKC} \zeta$ activity. ${ }^{4}$ Growing evidence indicates that phosphorylation is also a crucial event in regulation of PKC. PKC phosphorylation is a processing event that regulates maturation of the enzyme, in addition to regulating activation. ${ }^{2,5} \mathrm{PKC} \zeta$ is phosphorylated at Thr-410 in the activation loop by phosphoinositide-dependent protein kinase-1 (PDK1 ), and this phosphorylation is required for activity. $\mathrm{PKC} \zeta$ is also phosphorylated at Thr-560, which is an autophosphorylation site. ${ }^{5-8}$ Recently, it has been shown that phosphorylation at these sites controls not only $\mathrm{PKC} \zeta$ activity but also its turnover. $^{9}$

Chondrocyte apoptosis is believed to contribute to the pathogenesis of arthritis and cartilage destruction. ${ }^{10-12}$ Previous studies from our group indicate that direct production of nitric oxide (NO) via addition of the NO donor sodium nitroprusside (SNP) to primary culture articular chondrocytes causes apoptosis. ${ }^{13,14} \mathrm{PKC} \zeta$ functions as a survival signal during NO-induced apoptosis of articular chondrocytes since NO-induced chondrocyte apoptosis requires inhibition of PKC $\zeta{ }^{15-19}$ The PKC $\zeta$ inhibition occurs as a result of NOinduced p38 kinase activation and the inhibition of $\mathrm{PKC} \zeta$ activity is followed by proteolytic cleavage via the caspase-3dependent pathway. ${ }^{15}$ Our previous observation ${ }^{15}$ that inhibition of caspase-3 did not rescue the inhibition of $\mathrm{PKC} \zeta$ activity although cleavage of $\mathrm{PKC} \zeta$ was significantly abrogated clearly indicated that inhibition of $\mathrm{PKC} \zeta$ activity precedes its cleavage by caspase- 3 .

The aim of the present study was to investigate the molecular mechanisms underlying $\mathrm{PKC} \zeta$ inhibition by $\mathrm{p} 38$ kinase during NO-induced chondrocyte apoptosis. We report here a novel mechanism of $\mathrm{PKC} \zeta$ inhibition by p38 kinase. We 
demonstrated that following activation, p38 kinase directly interacts with the $\mathrm{PKC} \zeta_{\zeta}$ regulatory domain, thereby inhibiting the autophosphorylation required for $\mathrm{PKC}_{\zeta}$ activation.

\section{Results}

\section{p38 kinase-dependent inhibition of PKC $\zeta$ during NO-induced apoptosis of articular chondrocytes}

Consistent with previous observations, ${ }^{15}$ we found addition of the NO donor, SNP, to primary monolayer cultures of rabbit articular chondrocytes transiently activated p38 kinase (Figure 1a, upper panel). NO production also caused a decrease in protein level and activity of $P K C \zeta$. The decrease in $\mathrm{PKC} \zeta$ protein level was independent of its transcript level as determined by RT-PCR (Figure 1b, lower panel). This is consistent with our previous demonstration that $\mathrm{NO}$ inhibits $\mathrm{PKC} \zeta$ activity and stimulates subsequent proteolysis by caspase-3. ${ }^{15}$ Inhibition of NO-induced p38 kinase activation by the specific inhibitor SB203580 ${ }^{20}$ blocked the decrease in $\mathrm{PKC} \zeta$ protein level and activity (Figure $1 \mathrm{~b}$ ), and also blocked
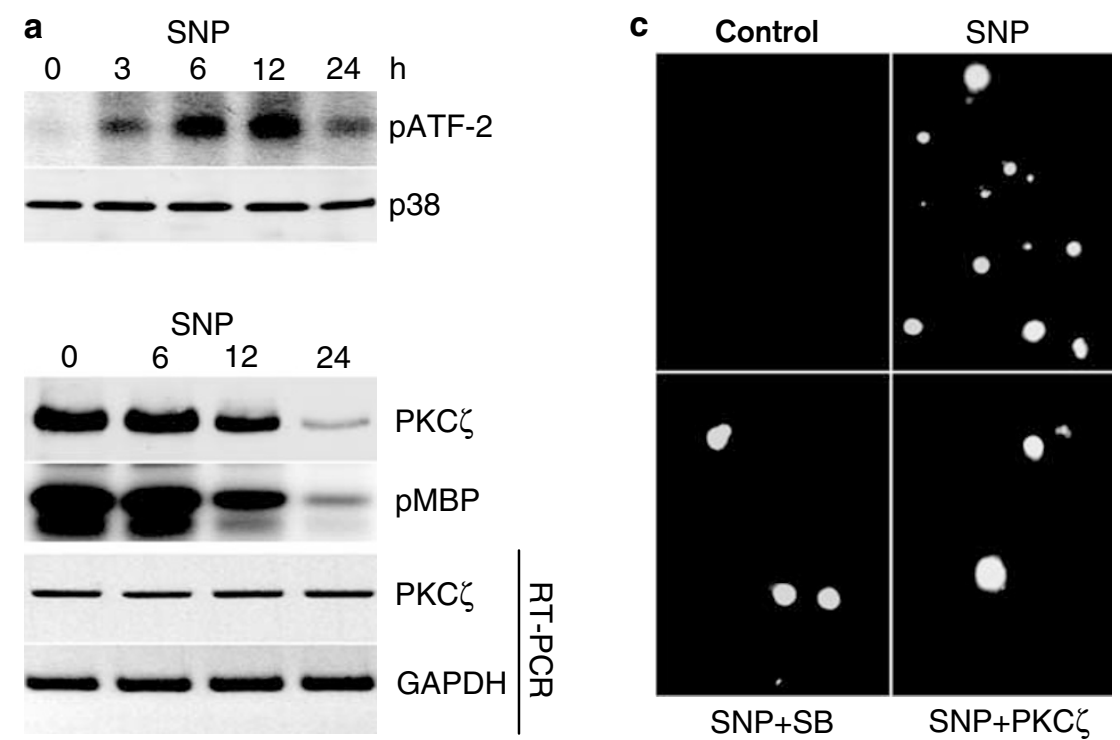

b

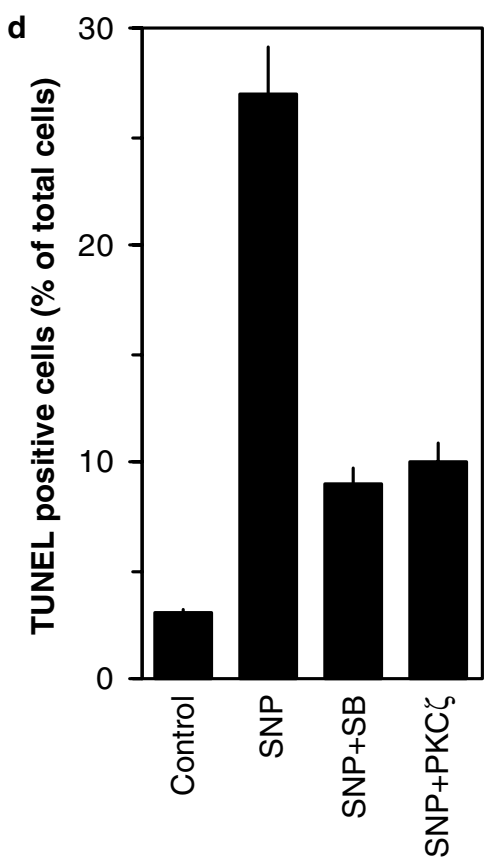

Figure 1 NO-induced activation of p38 kinase inhibits expression and activity of PKC $\zeta$ in chondrocytes. (a, b) Articular chondrocytes were treated with $1 \mathrm{mM}$ SNP (NO donor) for the indicated time period (a) or $1 \mathrm{mM} \mathrm{SNP}$ for $12 \mathrm{~h}$ (upper panel) or $24 \mathrm{~h}$ (lower panel) in the absence or presence of the indicated concentrations ( $\mu \mathrm{M}$ ) of SB203580 (b). Levels of p38 kinase and PKC $\zeta$ proteins were determined by Western blot analysis, and the activities were determined by immune complex kinase assays using ATF-2 and MBP as p38 kinase and PKC $\zeta$ substrates, respectively. mRNA levels of PKC $\zeta$ and glyceraldehyde 3-phosphate dehydrogenase (GAPDH) were determined by RT-PCR. (c, d) Chondrocytes were infected with control adenovirus or adenovirus carrying cDNA for wild-type PKC $\zeta$. Infected cells were cultured in complete medium for $24 \mathrm{~h}$ and treated with $1 \mathrm{mM}$ SNP for an additional $24 \mathrm{~h}$. Apoptotic cells were identified by TUNEL assay (c), and quantified by flow cytometry (d). The data in (a-c) represent a typical result from at least four independent experiments, and in (d) represent mean and standard deviation $(n=5)$ 
NO-induced apoptosis (Figure 1c and d). NO-induced apoptosis was also blocked by ectopic expression of wildtype $\mathrm{PKC} \zeta$ via adenovirus infection (Figure $1 \mathrm{c}$ and $\mathrm{d}$ ). The above results collectively indicate that $\mathrm{NO}$ production induces chondrocyte apoptosis through p38 kinase activation and subsequent inhibition of PKC $\zeta$.

\section{Direct interaction of p38 kinase with $\mathrm{PKC} \zeta$ via its regulatory domain}

To better understand p38 kinase-mediated inhibition of $\mathrm{PKC} \zeta$, we investigated a possible interaction between $\mathrm{PKC} \zeta$ and p38 kinase. $\mathrm{PKC} \zeta$ was overexpressed in chondrocytes using adenoviruses coding for wild-type $\mathrm{PKC} \zeta$. Immunoprecipitation of p38 kinase from lysates prepared from these cells resulted in co-precipitation of $\mathrm{PKC}_{\zeta}$ (Figure 2a), suggesting an interaction between $\mathrm{PKC} \zeta$ and p38 kinase. In addition, $\mathrm{PKC} \zeta$ coimmunoprecipitated with both p38 kinase and phosphorylated p38 kinase after addition of SNP to chondrocytes (Figure 2b). The complex formation between p38 kinase and $\mathrm{PKC} \zeta$ was blocked by the inhibition of p38 kinase activation with SB203580 (Figure 2c), indicating that p38 kinase activation is required for its association with $\mathrm{PKC} \zeta$.

We next examined whether p38 kinase interacted with $\mathrm{PKC} \zeta$ directly or indirectly via an intermediate protein. This was explored by in vitro assays using recombinant GST-p38 kinase fusion protein and recombinant $\mathrm{PKC} \zeta$ protein. A GST pull-down from the mixture of GST-p38 kinase and recombinant PKC $\zeta$ showed co-precipitation of PKC $\zeta$ (Figure 3a, left panel). Inversely, immunoprecipitation of $\mathrm{PKC} \zeta$ from the
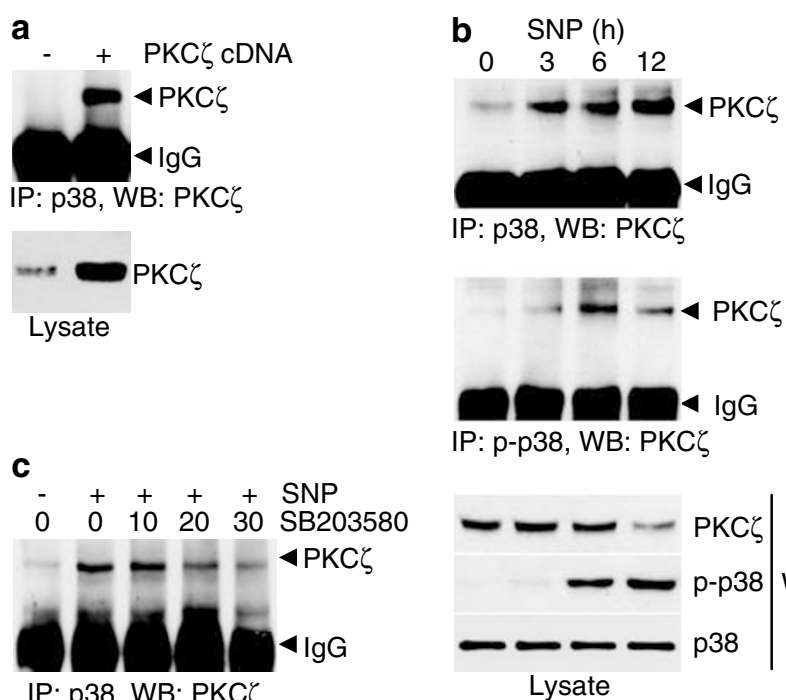

IP: p-p38, WB: PKC $\zeta$

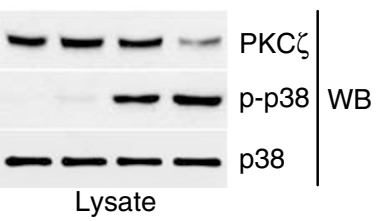

Figure $2 \mathrm{NO}$ causes physical association of p38 kinase with $\mathrm{PKC} \zeta$ in chondrocytes. Articular chondrocytes were infected with empty adenovirus or virus containing PKC $\zeta$ cDNA (a). Chondrocytes were treated with $1 \mathrm{mM} \mathrm{SNP} \mathrm{for}$ the indicated time periods in the absence (b) or presence of indicated concentrations $(\mu \mathrm{M})$ of SB203580 to inhibit p38 kinase (c). Total p38 kinase (p38) or phosphorylated p38 (p-p38) kinase was immunoprecipitated, and coprecipitation of PKC $\zeta$ was detected by Western blot analysis. Levels of PKC $\zeta$ phosphorylated p38 kinase and p38 kinase were determined by Western blot analysis (b, lower panel). The data represent a typical result from at least five independent experiments mixture showed co-precipitation of p38 kinase (Figure 3a, right panel). These in vitro data indicate a direct interaction between $\mathrm{p} 38$ kinase and $\mathrm{PKC} \zeta$. The interaction of p38 kinase with PKC appears to be specific for the $\zeta$ isoform among the PKC isoforms expressed in chondrocytes (i.e., $\alpha, \varepsilon$, and $\zeta$ ), since overexpressed $\mathrm{PKC} \alpha$ or $\mathrm{PKC} \varepsilon$ did not associate with p38 kinase (Figure 3b).

We investigated which $\mathrm{PKC} \zeta$ domain(s) was involved in the interaction with p38 kinase. Chondrocytes were engineered to overexpress myc-tagged wild-type $\mathrm{PKC} \zeta$, or myc-tagged PKC $\zeta$ regulatory or catalytic domains. Cell lysates were prepared, to which recombinant GST-p38 kinase was added, and the mixture was then analyzed in GST pull-down assays. Western blotting for the myc-tag revealed that both wild-type $\mathrm{PKC} \zeta$ and the $\mathrm{PKC} \zeta$ regulatory domain co-precipitated with GST-p38 kinase, while the $\mathrm{PKC} \zeta$ kinase domain did not (Figure 4). These data indicate that the $\mathrm{PKC} \zeta$ regulatory domain is responsible for the interaction with p38 kinase.

\section{p38 kinase inhibits $\operatorname{PKC} \zeta$ by blocking autophosphorylation}

We examined whether the interaction of p38 kinase with $\mathrm{PKC} \zeta$ was responsible for inhibition of $\mathrm{PKC} \zeta$ activity. Recombinant
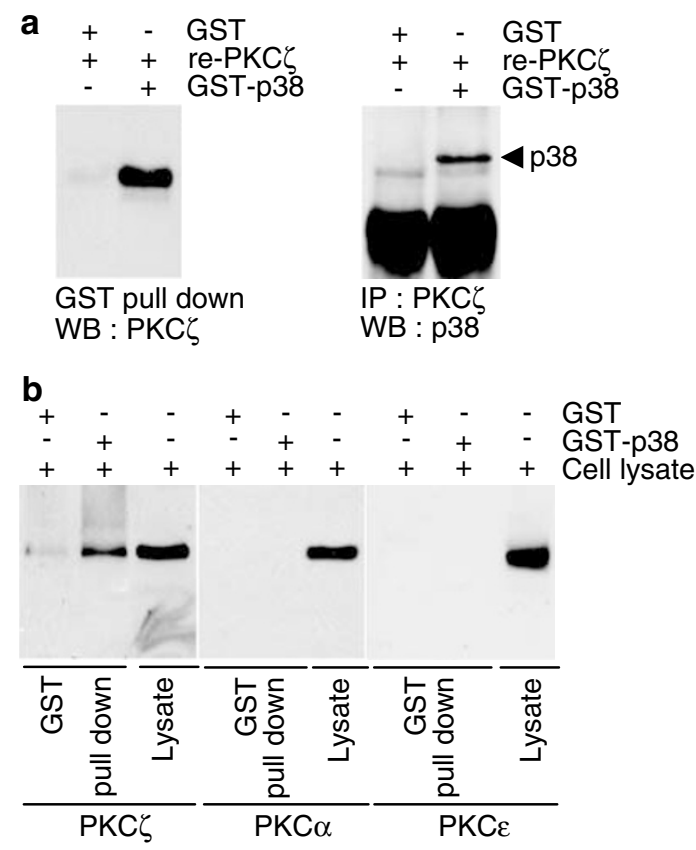

Figure 3 In vitro interaction of PKC $\zeta$ and p38 kinase. (a) GST or GST-p38 kinase $(1 \mu \mathrm{g})$ were incubated with recombinant PKC $\zeta(1 \mu \mathrm{g})$ for $4 \mathrm{~h}$ in NP-40 buffer ( $50 \mathrm{mM}$ Tris, pH 8.0, $150 \mathrm{mM} \mathrm{NaCl}, 1 \% \mathrm{NP}-40$ ). Following pull-down of GST or GST-p38 kinase with GST beads, or immunoprecipitation of PKC $\zeta$ with antibody, bound PKC $\zeta$ or p38 kinase was detected by Western blot analysis. (b) Chondrocytes were infected with adenovirus carrying $\mathrm{PKC} \zeta, \alpha$ or $\varepsilon \mathrm{CDNA}$, and infected cells were cultured in complete medium for $24 \mathrm{~h}$. Total cell lysates prepared from infected cells were incubated with recombinant GST or GST-p38 kinase $(1 \mu \mathrm{g})$ for $4 \mathrm{~h}$. Following GST pull-down, PKC $\zeta, \alpha$ or $\varepsilon$ were detected by Western blot analysis. Total cell lysates were used as a positive control for Western blot analysis. The data represent a typical result from at least five independent experiments 


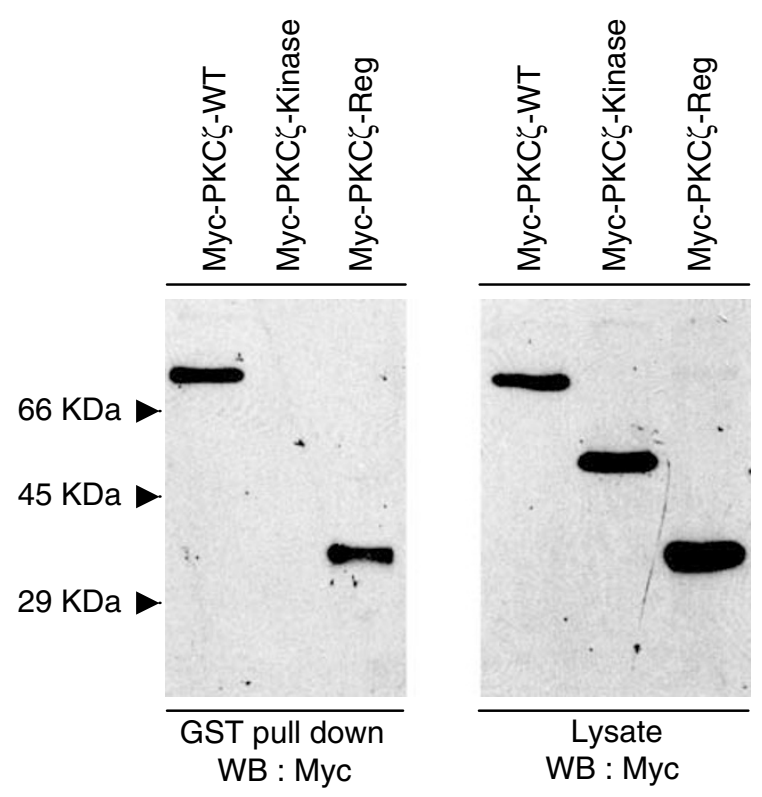

Figure 4 Regulatory domain of $\mathrm{PKC} \zeta$ interacts with p38 kinase. Articular chondrocytes were transfected with myc-tagged wild-type (WT) PKC $\zeta$, or myctagged PKC $\zeta$ regulatory (Reg) or kinase (Kinase) domain. Total cell lysates were prepared after $24 \mathrm{~h}$ culture in complete medium, and $500 \mu \mathrm{g}$ lysate was incubated with recombinant GST-p38 kinase $(1 \mu \mathrm{g})$ for $4 \mathrm{~h}$ at $4^{\circ} \mathrm{C}$. Following GST pull-down, co-precipitation of ectopically expressed $\mathrm{PKC} \zeta$ was determined by Western blotting using anti-myc antibody. Expression of PKC $\zeta$ was determined by Western blotting of total cell lysates. The data represent a typical result from at least four independent experiments

proteins or immunoprecipitated cellular proteins were used in these studies. We found that the in vitro activity of immunoprecipitated cellular $\mathrm{PKC} \zeta$ was reduced to $62 \%$ of control level by addition of recombinant GST-p38 kinase (Figure 5a). As expected, cellular $\mathrm{PKC}_{\zeta}$ activity was dramatically blocked by pseudosubstrate (PS)-PKC $\zeta$, and GST-p38 kinase itself did not phosphorylate the $\mathrm{PKC} \zeta$ substrate (Figure 5a). Recombinant $\mathrm{PKC} \zeta_{\zeta}$ activity was also reduced to 33 and $45 \%$ of control level by the addition of immunoprecipitated cellular p38 kinase or phosphorylated p38 kinase, respectively (Figure $5 \mathrm{~b}$ ). The effect of p38 kinase interaction on $\mathrm{PKC} \zeta$ activity was further investigated by overexpressing p38 kinase and/or PKC $\zeta$ in chondrocytes. Ectopically expressed myc-tagged PKC $\zeta$ activity was determined by immune complex kinase assay using anti-myc antibody. As shown in Figure $5 \mathrm{c}$ and $\mathrm{d}$, the activity of ectopically expressed $\mathrm{PKC} \zeta$ was significantly reduced by the coexpression of p38 kinase, indicating the inhibition of $\mathrm{PKC} \zeta$ activity by $\mathrm{p} 38$ kinase. While the association of $\mathrm{PKC} \zeta$ with $\mathrm{p} 38$ kinase resulted in lower PKC $\zeta$ activity, it did not affect p38 kinase activity (Figure 5e). Taken together, the above results suggest that binding of $\mathrm{p} 38$ kinase to $\mathrm{PKC} \zeta$ results in the inhibition of $\mathrm{PKC} \zeta$ activity.

We next examined the role of $\mathrm{PKC} \zeta$ phosphorylation in $\mathrm{p} 38$ kinase-mediated inhibition of $\mathrm{PKC} \zeta$ activity. It has been shown that human $\mathrm{PKC} \zeta$ is phosphorylated on Thr-410 and Thr-560. PDK-1 phosphorylates the Thr- 410 site, ${ }^{6,7}$ whereas Thr- 560 is reported to be an autophosphorylation site. ${ }^{8}$ We found that recombinant $\mathrm{PKC} \zeta$ was phosphorylated following the addition of $\left[\gamma-{ }^{32} \mathrm{P}\right]$ ATP alone, and that $\left[\gamma-{ }^{32} \mathrm{P}\right]$ ATP incorporation was blocked by addition of PS-PKC $\zeta$ or 'cold' ATP, suggesting autophosphorylation of $\mathrm{PKC} \zeta$ (Figure 6a). This $\mathrm{PKC} \zeta$ autophosphorylation was dramatically blocked by addition of recombinant GST-p38 kinase (Figure 6a), or by addition of cellular p38 kinase or phosphorylated p38 kinase immunoprecipitated from chondrocytes (Figure $6 b$ ). The effect was specific to p38 kinase since bead alone or the related ERK-1 did not affect PKC $\zeta$ phosphorylation (Figure 6b). In contrast to this inhibition of autophosphorylation, phosphorylation on Thr410 of recombinant $\mathrm{PKC} \zeta$ was not affected by addition of recombinant GST-p38 kinase, as determined by Western blot analysis (Figure 6a). Furthermore, addition of SNP to articular chondrocytes also did not affect PKC $\zeta$ Thr-410 phosphorylation (Figure 6c). These data indicate that neither NO nor p38 kinase affect PKC $\zeta$ Thr-410 phosphorylation. Taken together, these results suggest p38 kinase inhibits $\mathrm{PKC} \zeta$ activity via direct interaction and subsequent blocking of $\mathrm{PKC} \zeta$ autophosphorylation

\section{Micro LC-MS/MS analysis of PKC $\zeta$ autophosphorylation sites}

MicroLC-MS/MS experiments were performed to identify autophosphorylation sites on $\mathrm{PKC} \zeta$. Control and autophosphorylated recombinant $\mathrm{PKC} \zeta$ protein were reduced and alkylated with iodoacetamide, digested with proteolytic enzymes (chymotrypsin, proteinase $\mathrm{K}$, endoproteinase Lys-C or trypsin), and analyzed by microLC-MS/MS Digested peptides from the four different proteolytic enzymes were combined to cover all phosphorylation sites present in $\mathrm{PKC} \zeta$ and to confidently identify closely situated modification sites in a single peptide. A total of six modification sites were identified from control and autophosphorylated $\mathrm{PKC} \zeta$ proteins, which comprised four newly identified phosphorylation sites (i.e., Ser-113, Ser-186, Ser-217/Ser-218 and Ser-520) and two known phosphorylation sites (i.e., Thr-410 and Thr560) (Figure 7). Since MS/MS spectra from ion trap mass spectrometry often fail to provide sufficient information on very small fragment ions (e.g., $b_{1}, y_{1}, b_{2}$ and $y_{2}$ ), it was not easy to confidently assign phosphorylation sites among three consecutive serine residues, ${ }^{216}$ SerSerSer ${ }^{218}$. . However, Ser-216 can be ruled out because ${ }^{217}$ SS*RKHDSIK DDSEDLKPVIDGM DGIKIS ${ }^{244}$ obtained from proteinase $\mathrm{K}$ digestion was identified as a phosphorylated peptide.

Selected ion chromatograms of phosphorylated peptides were compared between control and autophosphorylated recombinant $\mathrm{PKC} \zeta$ to determine autophosphorylation sites. Phosphorylated peptides containing Ser-113 and Ser-186 were dramatically increased in autophosphorylated $\mathrm{PKC} \zeta$ (Figure $8 \mathrm{a}$ and $\mathrm{b}$ ). Control PKC $\zeta$ contained phosphorylated Thr-560, which is a known autophosphorylation site. Thr-560 phosphorylation was increased in autophosphorylated PKC $\zeta$ protein, although the degree of increase (1.9-fold) was less than that of Ser-113 or Ser-186 (Figure 8c). In contrast, the relative abundance of phosphorylated peptides containing Ser-217/218 and Ser-520 was not significantly different between control and autophosphorylated $\mathrm{PKC} \zeta$ (data not shown). Therefore, ion chromatogram analysis indicates that Ser-113, Ser-186 and Thr-560 can be autophosphorylated in $\mathrm{PKC} \zeta$ protein. 
a

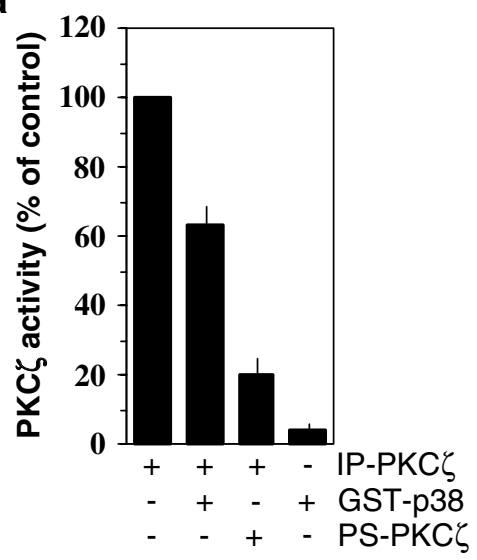

C

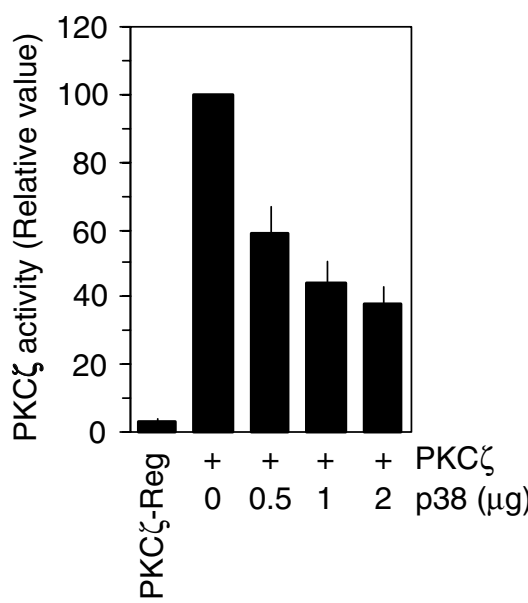

b

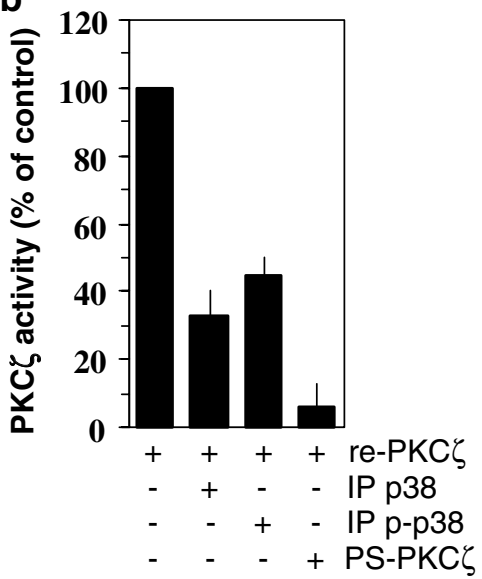

d

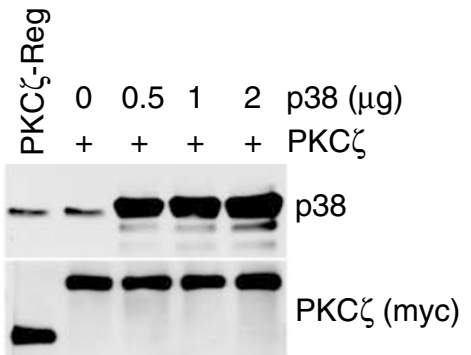

e

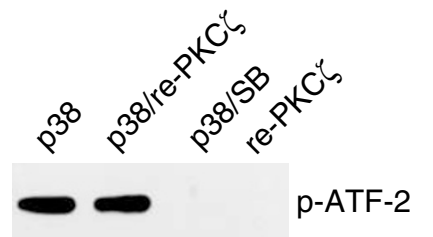

Figure 5 p38 kinase inhibits PKC $\zeta$ activity. (a) Cellular PKC $\zeta$ was immunoprecipitated from control chondrocyte cultures, and the immune complex (IP-PKC $\zeta$ ) was incubated with recombinant GST-p38 kinase $(0.3 \mu \mathrm{g})$ or PS-PKC $\zeta(30 \mu \mathrm{M})$. PKC $\zeta$ activity was determined using a kinase assay kit. (b) Recombinant PKC $\zeta$ (re-PKC $\zeta$, $0.1 \mu \mathrm{g}$ ) was incubated for $4 \mathrm{~h}$ with p38 kinase (IP p38) or phosphorylated p38 kinase (IP p-p38) (both immunoprecipitated from control chondrocyte cultures), or PSPKC $\zeta(30 \mu \mathrm{M})$. PKC $\zeta$ activity was determined using an assay kit. (c, d) Articular chondrocytes were transfected with $1 \mu \mathrm{g}$ of myc-tagged PKC $\zeta$ regulatory domain (PKC $\zeta-$ Reg) or wild type (PKC $\zeta$ ) and the indicated amount of p38 kinase (p38). Cells were cultured for $48 \mathrm{~h}$. Following immunoprecipitation of PKC $\zeta$ using anti-myc antibody, PKC $\zeta$ activity was determined using an assay kit (c). Expression of p38 kinase and PKC $\zeta$ (using anti-myc antibody) was determined by Western blot analysis (d). (e) Recombinant GST-p38 kinase $(1 \mu \mathrm{g})$ was incubated alone (p38) or with recombinant PKC $\zeta(1 \mu \mathrm{g})$ or $20 \mu \mathrm{M}$ SB203580 (SB) for $1 \mathrm{~h}$. p38 kinase activity was determined by in vitro kinase assay using ATF-2 as a substrate. Phosphorylation of ATF-2 was detected by Western blot analysis. The data in (a-c) represent mean and standard deviation, and in (d) and (e) represent a typical result from at least four independent experiments

To determine the significance of the inhibition of autophosphorylation by $\mathrm{p} 38$ kinase binding, myc-tagged $\mathrm{PKC} \zeta$ mutants (S113A, S186A, and T560A) were ectopically expressed and kinase activity was monitored by immune complex kinase assy. As shown in Figure 9, point mutation on Ser-113 or Ser186 or double mutation on both sites did not affect kinase activity, whereas mutation of Thr-560 to alanine dramatically blocked kinase activity. The above results collectively indicate that inhibition of autophosphorylation on Thr-560, but not Ser113 and Ser-186, is responsible for the inhibition of $\mathrm{PKC} \zeta$ activity by the binding of p38 kinase.

\section{Discussion}

This study investigated the mechanisms underlying p38 kinase-mediated inhibition of $\mathrm{PKC} \zeta$ following the addition of an NO donor to chondrocytes. As depicted in Figure 10, our data indicate that $\mathrm{PKC} \zeta$ activity was inhibited following p38 kinase activation due to a direct physical interaction between the two molecules. Furthermore, our data indicate the reason this interaction inhibited $\mathrm{PKC} \zeta$ activity was because the association reduced $\mathrm{PKC} \zeta$ autophosphorylation on Thr-560. Thus, our results provide evidence of a novel mechanism for $\mathrm{PKC} \zeta$ inhibition by $\mathrm{p} 38$ kinase. In relation to other known $\mathrm{PKC} \zeta$ inhibitors, Par-4 is known to bind to the regulatory domain of $\mathrm{PKC}_{\zeta}$ and inhibit its activity. ${ }^{4}$ It is unlikely that Par- 4 is involved in p38 kinase-mediated $\mathrm{PKC} \zeta$ inhibition since we could not detect any changes in Par-4 levels as determined by Western blot analysis (data not shown).

p38 kinase and $\mathrm{PKC} \zeta$ play opposing roles in NO-induced apoptosis of primary culture articular chondrocytes. Activation of p38 kinase by NO functions as a proapoptotic signal, ${ }^{13,14}$ 
a

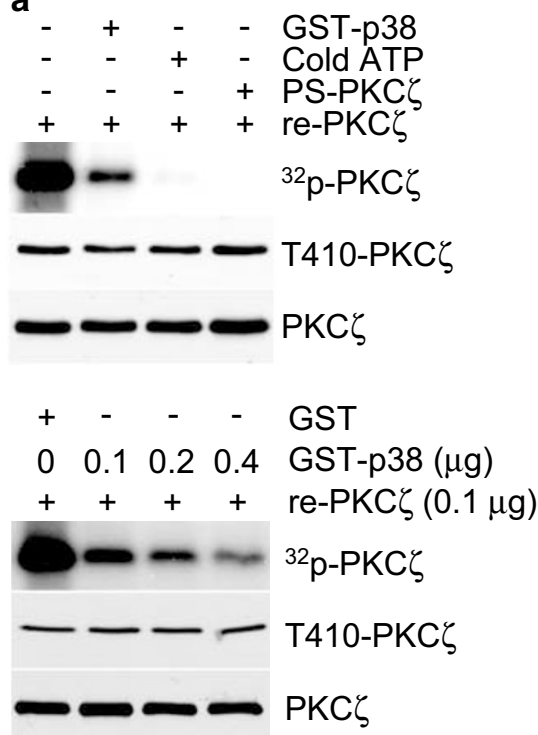

b

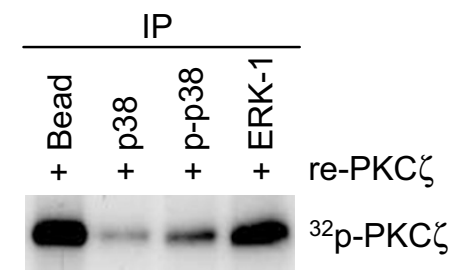

C

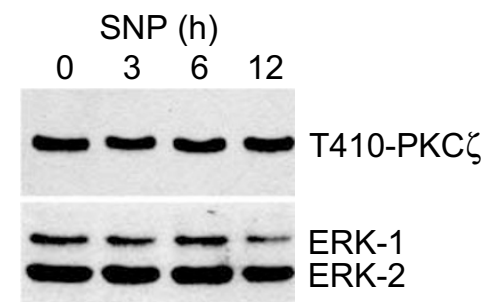

Figure 6 p38 kinase inhibits autophosphorylation of PKC $\zeta$. (a) Recombinant PKC $\zeta(0.1 \mu \mathrm{g})$ was preincubated alone or with GST-p38 kinase $(0.1 \mu \mathrm{g})$, PS-PKC $\zeta$ $(30 \mu \mathrm{M})$, or 'cold' ATP $(200 \mu \mathrm{M})$ for $4 \mathrm{~h}$ (upper panel). Alternatively, recombinant PKC $\zeta(0.1 \mu \mathrm{g})$ was incubated with the indicated amounts of GST-p38 kinase (lower panel). GST protein $(0.1 \mu \mathrm{g}$ ) was used as a negative control for GST-p38 kinase. The extent of PKC $\zeta$ autophosphorylation was measured by determining incorporation of $\left[\gamma-{ }^{32} \mathrm{P}\right]$ ATP using autoradiography. Levels of total PKC $\zeta$ and Thr-410-phosphorylated PKC $\zeta$ (T410-PKC $\zeta$ ) were determined by Western blot analysis. (b) Articular chondrocytes were treated with $1 \mathrm{mM}$ SNP for $12 \mathrm{~h}$. p38 kinase, phosphorylated p38 kinase, or ERK-1 was immunoprecipitated from total cell lysates and mixed with recombinant PKC $\zeta(0.1 \mu \mathrm{g})$. Following incubation for $4 \mathrm{~h}$, autophosphorylation of PKC $\zeta$ was determined by autoradiography. (c) Chondrocytes were treated with $1 \mathrm{mM}$ SNP for the indicated time period. Levels of Thr-410-phosphorylated PKC $\zeta$ and ERK were determined by Western blotting. The data represent a typical result from at least four independent experiments

with NO-induced apoptosis requiring downregulation of PKC $\zeta{ }^{15-19}$ The chondrocyte pro- and antiapoptotic functions of p38 kinase and $\mathrm{PKC} \zeta$, respectively, are also observed in other cell types. ${ }^{21-24}$ Evidence that $\mathrm{PKC} \zeta$ provides survival signals in chondrocytes is supported by the observations that ectopic expression of wild-type or constitutively active PKC $\zeta$ inhibited NO-induced apoptosis of articular chondrocytes, whereas inhibition of $\mathrm{PKC} \zeta$ activity by PS-PKC $\zeta$ potentiated NO-induced apoptosis. ${ }^{15}$ Currently, underlying molecular mechanism leading to the inhibition of p38 kinase-induced apoptosis of chondrocyte by $\mathrm{PKC} \zeta$ is not known. Our previous study indicated that p38 kinase causes chondrocyte apoptosis by accumulating $\mathrm{p} 53$ protein in two different ways, transcriptional activation by NF- $\kappa \mathrm{B}$ and post-translational stabilization. ${ }^{13}$ We have also shown that accumulation of p53 leads to the induction of $\mathrm{Bax},{ }^{14}$ translocation of Bax to the mitochondria (data not shown), and subsequent activation of caspase3. ${ }^{14}$ Ectopic expression of $\mathrm{PKC} \zeta_{\zeta}$ did not affect NO-induced p38 kinase activation but blocked downstream signaling such as NF- $\kappa \mathrm{B}$ activation, accumulation of $\mathrm{p} 53$, induction of Bax, and activation of caspase-3. ${ }^{15}$ We also observed that NO production in chondrocyte causes nuclear translocation of phosphorylated p38 kinase, p53, and $\mathrm{PKC} \zeta$ (data not shown). Nuclear translocation of $\mathrm{PKC} \zeta$ has also been observed in other cell type that coincides with the inhibition of apoptosis. ${ }^{25}$ Therefore, it is our hypothesis that $\mathrm{PKC} \zeta$ may function as an antiapoptotic signal by interrupting nuclear signaling such as $\mathrm{NF}-\kappa \mathrm{B}$ activation, p53 accumulation, and Bax expression.

The current results indicate that physical formation of a complex between $\mathrm{p} 38$ kinase and $\mathrm{PKC} \zeta$ is a critical step for the inhibition of $\mathrm{PKC} \zeta$ activity. While the principles underlying this interaction are yet to be fully identified, the present data show $\mathrm{PKC} \zeta$ and $\mathrm{p} 38$ kinase interact directly in vitro, suggesting the interaction does not require other proteins. It has been shown that p38 kinase can interact directly with numerous proteins with high specificity. ${ }^{26-28}$ This specific interaction is mediated by a binding domain on p38 kinase, known as the CD domain, and a specific interacting motif on the target molecule, known as the $\mathrm{D}$ domain. ${ }^{29}$ The $\mathrm{D}$ domain is found to form a modular structure, which comprises a cluster of positively charged amino-acid residues (LXL motif) surrounded by a hydrophobic region. Sequence analysis indicates $\mathrm{PKC} \zeta$ has a potential $D$ domain as it contains an LXL motif $\left({ }^{56} \mathrm{LTL}^{58}\right)$ and a hydrophobic pocket in its regulatory domain. ${ }^{30,31}$ That this potential $\mathrm{D}$ domain exists in the $\mathrm{PKC} \zeta$ regulatory domain is consistent with our present findings that p38 kinase interacts directly with $\mathrm{PKC} \zeta$ through its regulatory domain. In terms of identifying other factors involved in p38 kinase and $\mathrm{PKC} \zeta$ binding, the present study showed activation of p38 kinase was necessary for binding to $\mathrm{PKC} \zeta$, suggesting that phosphorylation of p38 kinase is required for its interaction with $\mathrm{PKC} \zeta$.

p38 kinase is a known Pro-directed Ser/Thr kinase. We initially hypothesized that p38 kinase inhibits $\mathrm{PKC} \zeta$ by phosphorylating $\mathrm{PKC} \zeta$. There are five possible (Ser/Thr)-Pro p38 kinase phosphorylation sites on $\mathrm{PKC} \zeta$, namely Ser-98, Thr-99, Thr-413, Ser-448 and Thr-559. The possibility that these sites are phosphorylated by p38 kinase was tested using recombinant GST-p38 kinase and synthetic peptides containing each site. MALDI-TOF analysis failed to detect phosphorylation of any of these peptides (data not shown), suggesting that $\mathrm{PKC} \zeta$ is not phosphorylated by p38 kinase. 

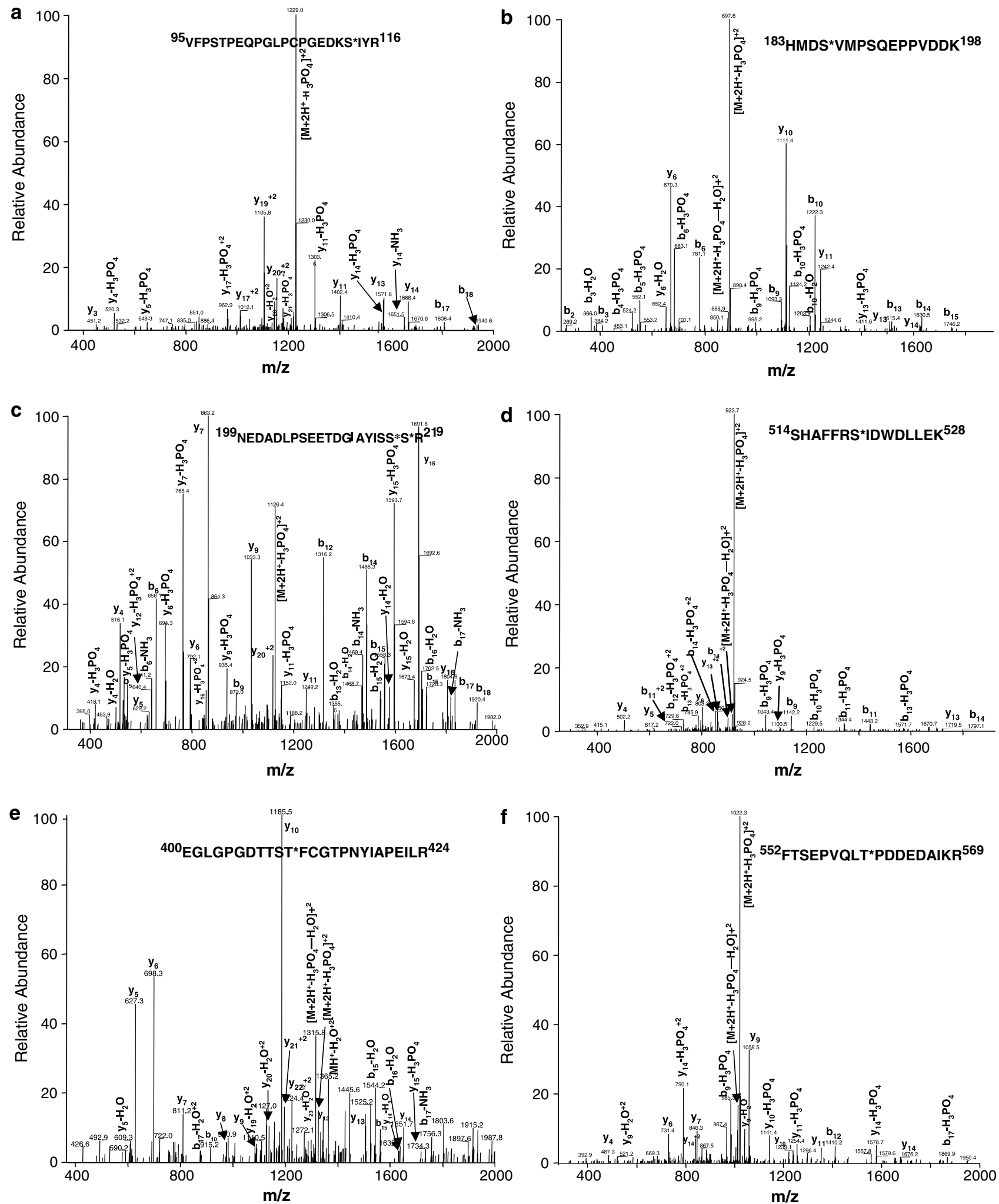

Figure 7 Mass spectrometry analysis of PKC $\zeta$ phosphorylation sites. Peptides were generated by trypsin digestion of autophosphorylated recombinant PKC $\zeta$. MS/MS spectra of tryptic peptides were acquired using $L C Q$ Deca XP Plus ion trap mass spectrometry. Peptide sequences and phosphorylation sites were identified using TurboSequest and Bioworks. The MS/MS spectra of six phosphorylated tryptic peptides are shown, indicating phosphorylation of Ser-113 (a), Ser-186 (b), Ser-216/217 (c), Ser-520 (d), Thr-410 (e) and Thr-560 (f). Fragment ions, especially b and y type ions, were assigned in each MS/MS spectra. Phosphorylation sites in each peptide are denoted with *. The data represent a typical result from at least three independent experiments 

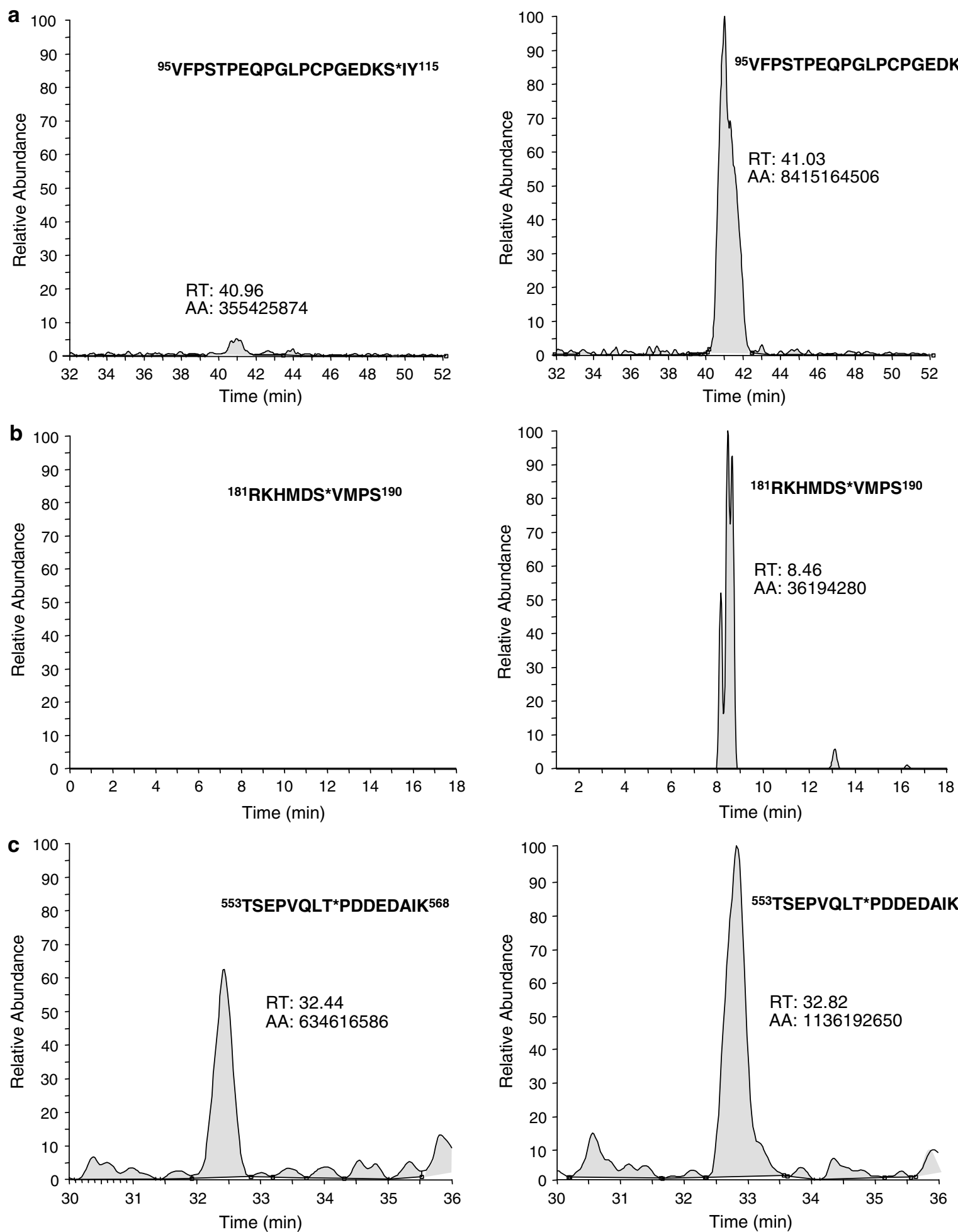

Figure 8 Quantitation of PKC $\zeta$ autophosphorylation. Control (left panel) and autophosphorylated (right panel) PKC $\zeta$ was digested with chymotrypsin (a and $\mathbf{c}$ ) or proteinase K (b). Ion chromatograms of peptides containing Ser-114 (a), Ser-186 (b) and Thr-560 (c) are shown. AA denotes the integrated peak area. The data represent a typical result from at least three independent experiments

Instead, our data indicate that p38 kinase inhibits $\mathrm{PKC} \zeta$ activity by inhibiting $\mathrm{PKC} \zeta$ autophosphorylation.

MicroLC/MS/MS analysis identified two known and four novel phosphorylation sites in $\mathrm{PKC} \zeta$. The known phosphorylation sites include Thr-560 in the Turn motif and Thr-410 in the activation loop. Thr-560 has been previously reported as an autophosphorylation site by several research groups. ${ }^{1,5,8}$ It has also been demonstrated that inhibition of 


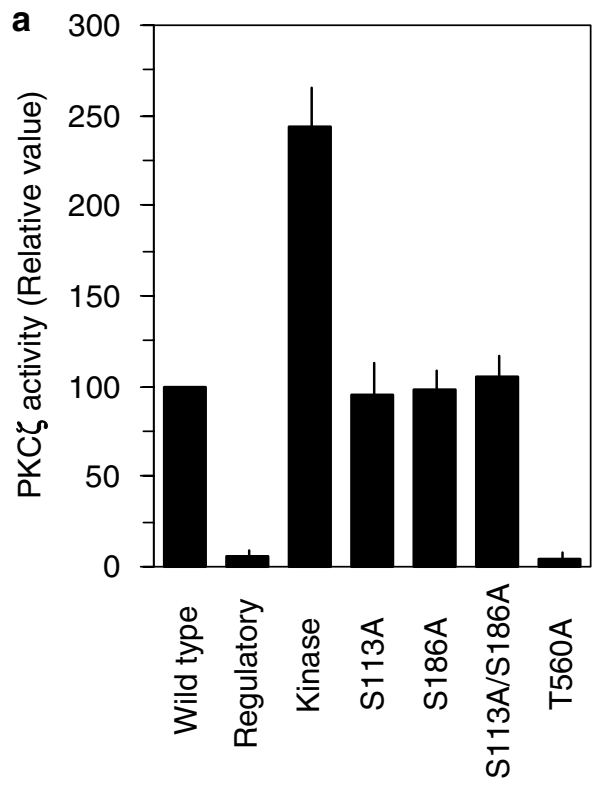

b

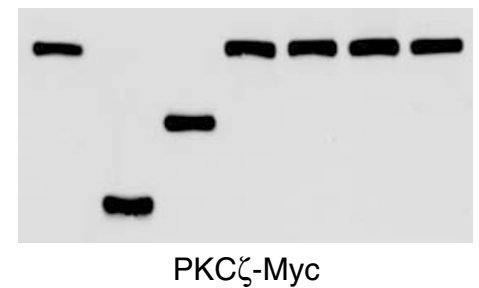

Figure 9 Inhibition of autophosphorylation on Thr-560 but not Ser-113 and Ser186 blocks PKC $\zeta$ activity. Chondrocytes were transfected with myc-tagged PKC $\zeta$ constructs: wild-type, kinase domain (Kinase), regulatory domain (Regulatory), S113A, S186A, S113A/S1686A, and Thr-560. Following immunoprecipitation using anti-myc antibody, PKC $\zeta$ activity was monitored by using an assay kit (a) Expression levels of individual PKC constructs was determined by Western blotting using anti-myc antibody (b). The data represent mean and standard deviation (a) and a typical result (b) from three independent experiments

Thr-560 autophosphorylation blocks $\mathrm{PKC} \zeta$ activity. ${ }^{8}$ Phosphorylation status of Thr-410, which is phosphorylated by PDK- $1,{ }^{6-8}$ was not affected by p38 kinase binding, indicating that p38 kinase does not interfere with Thr-410 phosphorylation by PDK-1. Among the novel phosphorylation sites identified by micro LC/MS/MS analysis, Ser-113 is located in the pseudosubstrate region, whereas Ser-186, Ser-217/218, and Ser-520 are not located in the specific motif or domain.

To identify autophosphorylation sites in $\mathrm{PKC} \zeta$, the degree of autophosphorylation was measured by comparing peak areas of corresponding peptide ion chromatogram of control and autophosphorylated samples. Although this may not be a widely accepted way to monitor changes in the degree of modification, it appears sufficient for relative quantification of an autophosphorylation in simple protein systems for the following reasons. First, ion chromatograms of nonmodified peptides were very similar for control and autophosphorylated protein samples. Second, autophosphorylation did not appear to alter the digestion patterns of $\mathrm{PKC} \zeta$, mostly yielding the same digested peptides. Using this technique, we identified Ser-113, Ser-186 and Thr-560 as autophosphorylation sites

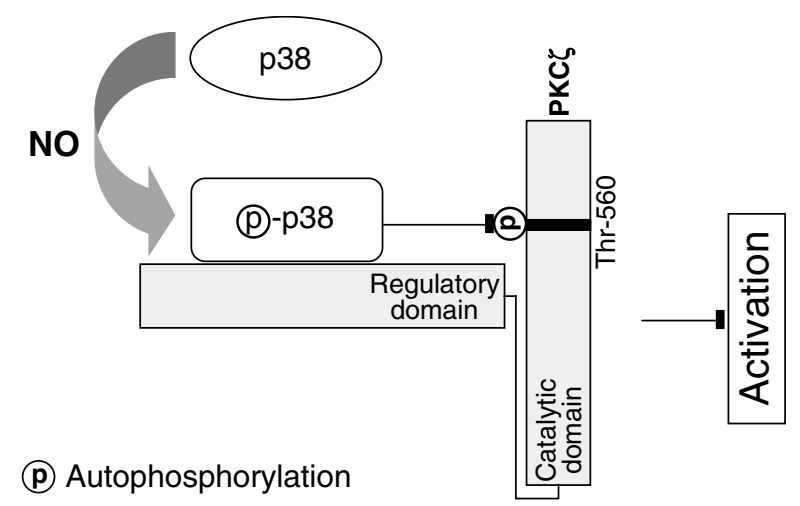

Figure 10 Schematic summary of $\mathrm{PKC} \zeta$ inhibition by $\mathrm{p} 38$ kinase. PKC $\zeta$ activity is inhibited following p38 kinase activation due to a direct physical interaction between the two molecules, and this interaction inhibited PKC $\zeta$ activity by blocking PKC $\zeta$ autophosphorylation on Thr-560

in PKC $\zeta$. Recombinant PKC $\zeta$ contains both unphosphorylated and phosphorylated Thr-560, and autophosphorylation increased the relative abundance of phosphorylated Thr-560. In contrast, Ser-113 and Ser-186 were not significantly phosphorylated in recombinant $\mathrm{PKC} \zeta$ protein, and autophosphorylation dramatically increased phosphorylation of these sites. Ser-113 and Ser-186 appear to be novel autophosphorylation sites, as we could not find any other reports regarding their autophosphorylation. However, inhibition of autophosphorylation in these sites by mutation did not affect $\mathrm{PKC} \zeta$ activity, whereas mutation in Thr-560 blocked $\mathrm{PKC} \zeta$ activation. While the principles underlying the inhibition of autophosphorylation are yet to be fully identified, it appears to be clear that inhibition of Thr-560 phosphorylation by p38 kinase binding is critical for the inhibition of $\mathrm{PKC} \zeta$ activation, and the functional significance of the autophosphorylation on Ser-113 and Ser-186 remains to be elucidated.

In summary, we demonstrated in this study that PKC $\zeta$ activity is inhibited following p38 kinase activation due to a direct physical interaction between the two molecules, and this interaction inhibited $\mathrm{PKC} \zeta$ activity by blocking $\mathrm{PKC} \zeta$ autophosphorylation on Thr-560. Thus, our results provide evidence of a novel mechanism for $\mathrm{PKC} \zeta$ inhibition by $\mathrm{p} 38$ kinase.

\section{Materials and Methods}

\section{Cell culture}

Articular chondrocytes were isolated from knee joint cartilage slices of 2-week-old New Zealand white rabbits by enzymatic digestion as described previously. ${ }^{32}$ Briefly, cartilage slices were dissociated enzymatically for $6 \mathrm{~h}$ in $0.2 \%$ collagenase type II ( $381 \mathrm{U} / \mathrm{mg}$ solid, Sigma, St. Louis, MO, USA) in Dulbecco's modified Eagle's medium (DMEM) (Gibco-BRL, Rockville, MD, USA). The cells were plated on culture dishes at a density of $5 \times 10^{4} \mathrm{cells} / \mathrm{cm}^{2}$ in DMEM containing $10 \%$ bovine serum. Cells at day 3.5 cultures were treated with various pharmacological reagents, as specified in each experiment. 


\section{Assay of apoptosis}

SNP-induced death of chondrocytes is due to apoptosis, as demonstrated by DNA fragmentation and terminal deoxynucleotidyl transfer-mediated nick end labeling (TUNEL). ${ }^{14}$ In this study, apoptotic cells were identified using TUNEL assays and quantified by analyzing $1 \times 10^{4}-2 \times 10^{4}$ cells using a FACSort flow cytometer.

\section{Construction of PKC mutants}

Constructs of myc-tagged wild-type $\mathrm{PKC} \zeta$ or myc-tagged $\mathrm{PKC} \zeta$ regulatory domain or catalytic domain were kindly provided by Dr. Peter J Parker (Cancer Research, UK). Point mutation to alanine of PKC $\zeta$ on Ser-113 (S113A), Ser-186 (S186A), Thr-560 (T560A), and double mutation on Ser113 and Ser-186 (S113A/S186A) was prepared by site-directed mutagenesis. Following mutagenizing oligonucleotides were used: $5^{\prime}$ CCTGGAGAAGACAAGGCCATCTACCGCCGTGG-3' for S113A mutant that substitutes a serine TCC codon to an alanine GCC codon, 5'GCATATGGATGCTGTCATGCCTTCCCAAG-3' for S186A that substitutes a serine TCT codon to an alanine GCT codon, and $5^{\prime}$ CGAGCCCGTACAGCTGGCCCCAGATGATGAGG-3' for T560A that substitutes a threonine ACC codon to an alanine GCC codon. Each construct with myc tag was ligated into pcDNA3 mammalian expression vector. Mutations were confirmed by sequence analysis.

\section{Ectopic expression of PKC $\zeta$ and p38 kinase}

Chondrocytes from day 3 cultures were infected with either control adenovirus or adenovirus containing wild-type mouse PKC $\zeta$ cDNA, as previously described, ${ }^{18}$ and infected cells were cultured in complete medium for $24 \mathrm{~h}$. In some experiments, infected cells were treated with $1 \mathrm{mM}$ SNP for an additional $12 \mathrm{~h}$. Alternatively, chondrocytes were transfected with plasmids coding for wild-type p38 kinase, myc-tagged PKC $\zeta$ wild-type, regulatory domain, catalytic domain, or mutants (S113A, S186A, T560A, and S113A/S186A) using LipofectAMINE PLUS (Invitrogen, Carlsbad, CA, USA) as previously described. ${ }^{19,33}$ The cells were cultured in complete medium for $24 \mathrm{~h}$ prior to further use.

\section{Immunoprecipitation and kinase assays}

The activity of cellular PKC $\zeta$ and $\mathrm{p} 38$ kinase was determined by immune complex kinase assay. Briefly, cell lysates were prepared in a lysis buffer (20 mM Tris-HCl, pH 7.5, 1 mM EDTA, 1 mM EGTA, $150 \mathrm{mM} \mathrm{NaCl}, 1 \%$ Triton X-100, $2.5 \mathrm{mM}$ sodium pyrophosphate, $1 \mathrm{mM} \beta$-glycerol phosphate) containing protease inhibitors $(10 \mu \mathrm{g} / \mathrm{ml}$ leupeptin, $10 \mu \mathrm{g} / \mathrm{ml}$ pepstatin A, $10 \mu \mathrm{g} / \mathrm{ml}$ aprotinin and $1 \mathrm{mM} \mathrm{4-(2-aminoethyl)} \mathrm{benzenesulfonyl} \mathrm{fluoride)}$ and phosphatase inhibitors ( $1 \mathrm{mM} \mathrm{NaF}$ and $1 \mathrm{mM} \mathrm{Na}_{3} \mathrm{VO}_{4}$ ). The cell lysates were precipitated with polyclonal antibody against p38 kinase, PKC $\zeta$, or myc tag (Santa Cruz Biotechnology Inc., Santa Cruz, CA, USA). Immune complexes were collected using protein $A$ sepharose beads and resuspended in $20 \mu \mathrm{l}$ kinase reaction buffer $(25 \mathrm{mM}$ Tris- $\mathrm{HCl}, \mathrm{pH} 7.5$, $5 \mathrm{mM} \beta$-glycerophosphate, $2 \mathrm{mM}$ dithiothreitol, $0.1 \mathrm{mM} \mathrm{Na}_{3} \mathrm{VO}_{4}, 10 \mathrm{mM}$ $\mathrm{MgCl}_{2},\left[\gamma_{-}{ }^{32} \mathrm{P}\right]$ ATP and $1 \mu \mathrm{g}$ substrate). Activating transcription factor-2 (ATF-2) (Santa Cruz Biotechnology Inc.) and myelin basic protein (MBP) (Sigma) were used as substrates for $\mathrm{p} 38$ kinase and $\mathrm{PKC} \zeta$, respectively.

Activities of human recombinant $\mathrm{PKC} \zeta$ protein (produced in Sf-9 cells) and recombinant GST-p38 kinase (Calbiochem, La Jolla, CA, USA) were determined by in vitro kinase assay. Recombinant $\mathrm{PKC} \zeta$ activity was determined using a SignaTECT PKC assay kit (Promega, Madison, WI, USA). Briefly, recombinant $\mathrm{PKC} \zeta(0.1 \mu \mathrm{g})$ was added to the kinase reaction buffer described above, supplemented with phosphatidylserine and PKC-biotinylated peptide substrate. The kinase reaction was performed for $5 \mathrm{~min}$ at $30^{\circ} \mathrm{C}$, and $\left[\gamma^{32} \mathrm{P}\right]$ ATP incorporation into peptide substrate was measured by scintillation counting. Recombinant GST-p38 kinase fusion protein $(0.1 \mu \mathrm{g})$ was added to $20 \mu$ l kinase reaction buffer, and the kinase reaction was performed for $30 \mathrm{~min}$ at $30^{\circ} \mathrm{C}$ using ATF-2 as a substrate. Phosphorylated ATF-2 was detected by Western blotting using an antiphosphorylated ATF-2 antibody (New England Biolabs, Beverly, MA, USA).

\section{Autophosphorylation of PKC $\zeta$}

Recombinant PKC $\zeta(0.1 \mu \mathrm{g})$ was incubated for $30 \mathrm{~min}$ at $30^{\circ} \mathrm{C}$ in the kinase reaction buffer described above, in the absence or presence of various reagents, as specified in each experiment. The autophosphorylation reaction was stopped by adding $2 \times$ SDS sample buffer. Following size-fractionation of $\mathrm{PKC} \zeta$ by electrophoresis on SDSpolyacrylamide gels, $\mathrm{PKC} \zeta$ phosphorylation was detected using autoradiography.

\section{GST pull-down assay}

GST or GST-p38 fusion protein $(1 \mu \mathrm{g})$ was incubated for $4 \mathrm{~h}$ on a rotator in a cold room with $1 \mu \mathrm{g}$ recombinant PKC $\zeta$ or $1 \mathrm{mg}$ total cell lysate prepared in NP-40 buffer (50 mM Tris, pH 8.0, $150 \mathrm{mM} \mathrm{NaCl}, 1 \% \mathrm{NP}-40$ ). GST or GST-p38 kinase complexes were collected using GST-beads and washed three times with NP-40 buffer. The bound proteins were size-fractionated by electrophoresis and detected using Western blotting.

\section{Western blot analysis}

Whole cell lysates were prepared by extracting proteins using a buffer (50 mM Tris-HCl, pH 7.4,. $150 \mathrm{mM} \mathrm{NaCl}, 1 \%$ Nonidet P-40 and 0.1\% SDS) supplemented with protease inhibitors and phosphatase inhibitors, as described above. The proteins were size-fractionated by SDS-polyacrylamide gel electrophoresis, transferred to a nitrocellulose membrane, and detected using specific antibodies. Antibodies against $\mathrm{PKC} \alpha, \mathrm{PKC} \varepsilon$, myctag, PKC $\zeta$ phosphorylated at Thr-410, phosphorylated ATF-2 and phosphorylated p38 kinase were purchased from New England Biolabs. Anti-PKC $\zeta$ and anti-p38 kinase were from Santa Cruz Biotechnology Inc. Blots were developed using a peroxidase-conjugated secondary antibody and enhanced chemiluminescence kit.

\section{Reverse transcription polymerase chain reaction (RT-PCR)}

Total RNA was isolated by a single-step guanidinium thiocyanate-phenol chloroform method, using RNA STAT-60 (Tel-Test B, Inc., Friendswood, TX, USA) according to the manufacturer's protocol. Total RNA ( $3 \mu \mathrm{g})$ was reverse-transcribed with AMV reverse transcriptase for $60 \mathrm{~min}$ at $42^{\circ} \mathrm{C}$, followed by PCR. PCR conditions were $94^{\circ} \mathrm{C}$ for $40 \mathrm{~s}, 50^{\circ} \mathrm{C}$ for $40 \mathrm{~s}$ and $72^{\circ} \mathrm{C}$ for $40 \mathrm{~s}$ for a total of 33 cycles. A pair of PCR primers was designed to amplify $\mathrm{PKC} \zeta \mathrm{mRNA}$ isolated from rabbit articular chondrocytes. PCR primers used were as follows: PKC $\zeta$ sense $5^{\prime}$-ACTACGGCATGTG CAAGG-3' and antisense 5'-GAACTGCGTGTCGGAGTTG- $3^{\prime}$, and glyceraldehyde 3-phosphate dehydrogenase (GAPDH) sense $5^{\prime}$-TCAC CATCTTCCAGGAGCGA-3' and antisense $5^{\prime}$-CACAAT GCCGAAGTG GTCGT-3'. PCR products were analyzed on $1.5 \%$ agarose gels and visualized by ethidium bromide staining. Sequencing of rabbit PKC $\zeta$ PCR product showed 92 and $88 \%$ homology to human and mouse PKC $\zeta$, respectively. 


\section{Enzymatic digestion for mass spectrometry analysis of PKC $\zeta$}

A measure of $1 \mu \mathrm{g}$ of control recombinant PKC $\zeta$ or autophosphorylated PKC $\zeta$ was reduced and alkylated by addition of dithiothreitol and iodoacetamide. To generate peptides covering different sequences, the samples were digested in a digestion buffer $(100 \mathrm{mM}$ Tris- $\mathrm{HCl}, \mathrm{pH} 7.8$, $10 \mathrm{mM} \mathrm{CaCl}$ ) with one of four different proteolytic enzymes (chymotrypsin, proteinase $\mathrm{K}$, endoproteinase Lys-C and trypsin). Digestion conditions were $14 \mathrm{~h}$ at $25^{\circ} \mathrm{C}$ for chymotrypsin, $1 \mathrm{~h}$ at $37^{\circ} \mathrm{C}$ for proteinase $\mathrm{K}, 14 \mathrm{~h}$ at $25^{\circ} \mathrm{C}$ for endoproteinase Lys-C and $14 \mathrm{~h}$ at $24^{\circ} \mathrm{C}$ for trypsin, with an enzyme to substrate ratio of $1: 100$. Protein digestion was quenched by adding $90 \%$ formic acid (final concentration of $5 \%$ ).

\section{Micro LC-MS/MS analysis of PKC $\zeta$}

Digested proteins were loaded onto fused silica capillary columns $(100 \mu \mathrm{m}$ i.d. , $360 \mu \mathrm{m}$ o.d.,) containing $8 \mathrm{~cm}$ of $5 \mu \mathrm{m}$ particle size Polaris $\mathrm{C}-18$ column material (Metachem, Ventura, CA, USA). The column was placed inline with an Agilent HP1100 quaternary LC pump and a splitter system was used to achieve a flow rate of $250 \mathrm{nl} / \mathrm{min}$. Buffer A ( $5 \%$ acetonitrile and $0.1 \%$ formic acid) and buffer $B(80 \%$ acetonitrile and $0.1 \%$ formic acid) were used to make a 110 min gradient. The gradient profile started with 5 min of $100 \%$ buffer $A$, followed by a 70 min gradient from 0 to $55 \%$ buffer $B$, a 30 min gradient from 55 to $100 \%$ buffer $B$, and a 5 min gradient of $100 \%$ buffer $B$. Eluted peptides were directly electrosprayed into an $L C Q$ Deca XP Plus mass spectrometer (ThermoFinnigan, Palo Alto, CA, USA) by applying $2.3 \mathrm{kV}$ of $\mathrm{DC}$ voltage. A data-dependent scan consisting of one full MS scan $(400-1400 \mathrm{~m} / \mathrm{z})$ and three data-dependent MS/MS scans was used to generate MS/MS spectra of eluted peptides. Normalized collision energy of $35 \%$ was used throughout the data acquisition. MS/MS spectra were searched against an in-house protein database containing the $\mathrm{PKC} \zeta$ sequence using TurboSequest and phosphorylation modification $(+80$ on Ser, Thr, Tyr) was considered in the differential modification search. Bioworks Ver 3.1 was used to filter the search results and the following Xcorr values were applied to different charge states of peptides: 1.8 for singly charged peptides, 2.5 for doubly charged peptides and 3.5 for triply charged peptides. MS/MS spectra for phosphorylated peptides were generated using Xcalibur Ver 3.1 and manual assignment of fragment ions was performed to confirm the search results. Changes in the level of phosphorylation before and after autophosphorylation reaction were monitored by selected ion monitoring of each phosphorylated peptide. Peak area was integrated using a built-in integration function of Xcalibur.

\section{Acknowledgements}

We thank Dr. Peter J Parker (Cancer Research, UK) for his kind gift of myc-PKC $\zeta$ cDNA constructs. This work was supported by the National Research Laboratory Program (M1-0104-00-0064) from the Korea Ministry of Science and Technology and The Interdisciplinary Research Project (1999-2-207-004-5) from the Korea Science and Engineering Foundation.

\section{References}

1. Toker A (1998) Signaling through protein kinase C. Front Biosci. 3: D1134D1147

2. Liu WS and Heckman CA (1998) The sevenfold way of PKC regulation. Cell Signal 10: 529-542
3. Ron D and Kazanietz MG (1999) New insights into the regulation of protein kinase $C$ and novel phorbol ester receptors. FASEB J. 13: 1658-1676

4. Diaz-Meco MT, Municio MM, Frutos S, Sanchez P, Lozano J, Sanz L and Moscat J (1996) The product of par-4, a gene induced during apoptosis, interacts selectively with the atypical isoforms of protein kinase C. Cell 86: 777-786

5. Parekh DB, Ziegler W and Parker PJ (2000) Multiple pathways control protein kinase C phosphorylation. EMBO J. 19: 496-503

6. Dutil EM, Toker A and Newton AC (1998) Regulation of conventional protein kinase $C$ isozymes by phosphoinositide-dependent kinase 1 (PDK-1). Curr. Biol. 8: 1366-1375

7. Le Good JA, Ziegler WH, Parekh DB, Alessi DR, Cohen P and Parker PJ (1998) Protein kinase C isotypes controlled by PI3 K through the protein kinases PDK1. Science 281: 2042-2045

8. Standaert ML, Bandyopadhyay G, Kanoh Y, Sajan MP and Farese RV (2001) Insulin and PIP3 activate PKC-zeta by mechanisms that are both dependent and independent of phosphorylation of activation loop (T410) and autophosphorylation (T560) sites. Biochemistry 40: 249-255

9. Le Good JA and Brindley DN (2004) Molecular mechanisms regulating protein kinase C-zeta turnover and cellular transformation. Biochem. J. 378: 83-92

10. Amin AR and Abramson SB (1998) The role of nitric oxide in articular cartilage breakdown in osteoarthritis. Curr. Opin. Rheumatol. 10: 263-268

11. Amin AR, Attur M and Abramson SB (1999) Nitric oxide synthase and cyclooxygenase: distribution regulation and intervention in arthritis. Curr. Opin. Rheumatol. 11: 202-209

12. Sandell $L J$ and Aigner $T$ (2001) Articular cartilage and changes in arthritis. An introduction: cell biology of osteoarthritis. Arthritis Res. 3: 107-113

13. Kim SJ, Hwang SG, Shin DY, Kang SS and Chun JS (2002) p38 kinase regulates nitric oxide-induced apoptosis of articular chondrocytes by accumulating p53 via NFkappa B-dependent transcription and stabilization by serine 15 phosphorylation. J. Biol. Chem. 277: 33501-33508

14. Kim SJ, Ju JW, Oh CD, Yoon YM, Song WK, Kim JH, Yoo YJ, Bang OS, Kang SS and Chun JS (2002) ERK-1/2 and p38 kinase oppositely regulate nitric oxide-induced apoptosis of chondrocytes in association with p53, caspase-3, and differentiation status. J. Biol. Chem. 277: 1332-1339

15. Kim SJ, Kim HG, Oh CD, Hwang SG, Song WK, Yoo YJ, Kang SS and Chun JS (2002) p38 kinase-dependent and -independent inhibition of protein kinase $C$ zeta and -alpha regulates nitric oxide-induced apoptosis and dedifferentiation of articular chondrocytes. J. Biol. Chem. 277: 30375-30381

16. Kim SJ and Chun JS (2003) Protein kinase $C$ alpha and zeta regulate nitric oxide-induced NF-kappa B activation that mediates cyclooxygenase-2 expression and apoptosis but not dedifferentiation in articular chondrocytes. Biochem. Biophys. Res. Commun. 303: 206-211

17. Kim SJ, Hwang SG, Kim IC and Chun JS (2003) Actin cytoskeletal architecture regulates nitric oxide-induced apoptosis, dedifferentiation, and cyclooxygenase-2 expression in articular chondrocytes via mitogen-activated protein kinase and protein kinase C pathways. J. Biol. Chem. 278: 4244842456

18. Yoon JB, Kim SJ, Hwang SG, Chang S, Kang SS and Chun JS (2003) Nonsteroidal anti-inflammatory drugs inhibit nitric oxide-induced apoptosis and dedifferentiation of articular chondrocytes independent of cyclooxygenase activity. J. Biol. Chem. 278: 15319-15325

19. Oh CD and Chun JS (2003) Signaling mechanisms leading to the regulation of differentiation and apoptosis of articular chondrocytes by insulin-like growth factor-1. J. Biol. Chem. 278: 36563-36571

20. Cuenda A, Rouse J, Doza YN, Meier R, Cohen P, Gallagher TF, Young PR and Lee J C (1995) SB 203580 is a specific inhibitor of a MAP kinase homologue which is stimulated by cellular stresses and interleukin-1. FEBS Lett. 364: 229-233

21. Xia Z, Dickens M, Raingeaud J, Davis RJ and Greenberg ME (1995) Opposing effects of ERK and JNK-p38 MAP kinases on apoptosis. Science 270: $1326-1331$

22. Ichijo $H$, Nishida E, Irie K, ten Dijke $P$, Saitoh M, Moriguchi T, Takagi M, Matsumoto K, Miyazono K and Gotoh Y (1997) Induction of apoptosis by ASK1, a mammalian MAPKKK that activates SAPK/JNK and p38 signaling pathways. Science 275: 90-94

23. Berra E, Municio MM, Sanz L, Frutos S, Diaz-Meco MT and Moscat J (1997) Positioning atypical protein kinase $\mathrm{C}$ isoforms in the UV-induced apoptotic signaling cascade. Mol. Cell Biol. 17: 4346-4354 
24. Moscat J, Sanz L, Sanchez P and Diaz-Meco MT (2001) Regulation and role of the atypical PKC isoforms in cell survival during tumor transformation. Adv. Enzyme Regul. 41: 99-120

25. Kronfeld I, Kazimirsky G, Gelfand EW and Brodie C (2002) NGF rescues human $B$ lymphocytes from anti-lgM induced apoptosis by activation of PKCzeta. Eur. J. Immunol. 32: 136-143

26. Weston CR, Lambright DG and Davis RJ (2002) Signal transduction. MAP kinase signaling specificity. Science 296: 2345-2347

27. Tanoue $T$ and Nishida E (2003) Molecular recognitions in the MAP kinase cascades. Cell Signal 15: 455-462

28. Cox EH (2002) MAPping p38 binding interactions. Nat. Struct. Biol. 9: 569

29. Chang Cl, Xu BE, Akella R, Cobb MH and Goldsmith EJ (2002) Crystal structures of MAP kinase p38 complexed to the docking sites on its nuclear substrate MEF2A and activator MKK3b. Mol. Cell 9: 1241-1249
30. Bardwell AJ, Abdollahi M and Bardwell $L$ (2003) Docking sites on mitogenactivated protein kinase (MAPK) kinases, MAPK phosphatases and the Elk-1 transcription factor compete for MAPK binding and are crucial for enzymic activity. Biochem. J. 15: 1077-1085

31. Tanoue T, Maeda R, Adachi M and Nishida E (2001) Identification of a docking groove on ERK and p38 MAP kinases that regulates the specificity of docking interactions. EMBO J. 20: 466-479

32. Yoon YM, Kim SJ, Oh CD, Ju JW, Song WK, Yoo YJ, Huh TL and Chun JS (2002) Maintenance of differentiated phenotype of articular chondrocytes by protein kinase $\mathrm{C}$ and extracellular signal-regulated protein kinase. J. Biol. Chem. 277: 8412-8420

33. Ryu JH, Kim SJ, Kim SH, Oh CD, Hwang SG, Chun CH, Oh SH, Seong JK, Huh TL and Chun JS (2002) Regulation of the chondrocyte phenotype by betacatenin. Development 129: 5541-5550 